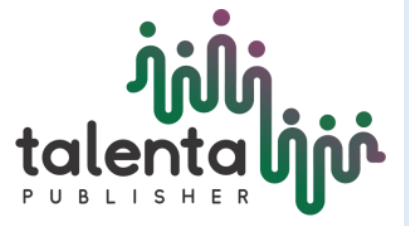

Intepnational doupmal of Ecophysiology

\title{
Rearing of Local Earthworms in The Mixed Media of Bagasse and Fish Waste
}

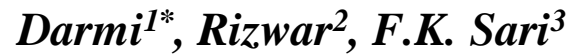 \\ ${ }^{1,2,3}$ Department of Biology FMIPA Universitas Bengkulu, Jalan WR Supratman Kandang Limun Kota \\ Bengkulu
}

\begin{abstract}
This study aims to determine the preference of earthworms to a media, their population growth in the media, and their ability to produce vermicompost. This study was designed with a completely randomized design consisted of three (3) treatments and each treatment consisted of 7 replications. The treatments in this study were 3 species of local earthworms (Pheretima javanica, Pheretima asiatica, and Pontoscolex corethrurus). The rearing media used was the mixture of bagasse and fish waste. The parameters studied were the time needed by the earthworms to enter the media, the earthworms population growth rate, and the time needed by the earthworms in producing vermicompost. The results showed the three species tested could be lived on mixed media of bagasse and fish waste. The worm's preference to the media was determined based on the time of earthworms entering media. The fastest was Pheretima javanica ( 0.23 minutes), followed by Pheretima asiatica (3.09 minutes) and Pontoscolex corethrurus (6.94 minutes) $(\mathrm{p}<0.05)$. The population growth rate between Pheretima javanica (5.85) and Pheretima asiatica (5.71) was not significantly different, but both significantly higher than Pontoscolex corethrurus (0.29 individual/month). The time for vermicompost formation in Pheretima javanica (6 weeks) and Pheretima asiatica (6 weeks) was not significantly different, but they were significantly lower from the time for vermicompost formation in Pontoscolex corethrurus (8 weeks).
\end{abstract}

Keywords: Pheretima javanica, Pheretima asiatica, Pontoscolex corethrurus, bagasse, fish waste.

Received 19 November 2018 | Revised 20 December 2018 | Accepted 20 January 2019

\section{Introduction}

Earthworms are one of the soil organism groups that play a role in decomposing organic waste. The use of earthworms in the decomposition of organic waste is one of the efforts to increase the value of waste or organic waste. Organic waste / organic waste is a source of food and a medium for breeding earthworms (Edward and Lofty, 1972; Kavdir and Ilay, 2011).

\footnotetext{
*Corresponding author at: Jalan WR Supratman Kandang Limun Kota Bengkulu, Indonesia

E-mail address: bucharidarmi@gmail.com
} 
Earthworms are divided into 3 main groups based on their eating habits and activities to make burrows on the ground namely anecic, endogeic and epigeic. Anecic worms, living in deeper soil layers can reach several meters from the soil surface and actively dig holes vertically, for example, Lumbricus terretris. Endogeic worms are worms that live in layers of topsoil, generally on mineral soils, for example, Aporrectodea tuberculata. The body of this worm is pale and very sensitive to light. This group of worms consumes litter incorporated in the topsoil layer. Epigeic worms, live in layers of litter or soil surface layer and also known as compost worms. Generally, epigeic worms have red-brownish body pigments and consume litter on the soil surface, for example, Eisenia fetida and Pheretima asiatica (Lee, 1985; But and Lowe, 2011).

Epigeic worm groups are the main choice. For the needs of worm breeding, both for reshaping organic matter (making vermicompost) or for cultivating earthworms, epigeic worms are also known as compost worms and are able to process large amounts of organic material and breed faster than endogeic and anecic worms (Dominguez and Edwards, 2011). Gunadi (2011) also states that the type of Phretima sp. also has the potential to be cultivated. Pheretima sp is classified as an epigeic worm and has the potential to be used as a compost worm or can be used as a decomposition agent in vermicomposting techniques.

A lot of organic waste is still not used optimally, including bagasse waste and fish waste. The availability of bagasse waste is quite abundant and has the potential as a compost raw material. Rahimah et al. (2015) showed that bagasse compost was able to increase the growth of Acacia crassicarpa seedlings. Fish waste is wet organic waste which is also abundant in traditional markets. Davis et al. (2004) stated that the use of fish waste as organic fertilizer has been carried out. Until now there have been many types of organic fertilizer circulating based on fish waste, either as solid fertilizer or liquid fertilizer. Solid fertilizer is generally in the form of granules or pellets, whereas in liquid form is a high concentration emulsion.

Bagasse waste mixture and fish waste is a combination of solid (dry) waste and wet (liquid) waste techniques and is also a combination of organic fiber-rich waste with protein-rich organic waste. Mixing solid waste (bagasse) and wet waste (fish waste), is assumed to be potentially used as a good medium for the maintenance of earthworms. In connection with this, it is necessary to do research on testing several species of local earthworms in a mixture of bagasse waste media and fish waste. This study aims to determine the level of worm preference on media, growth rate and the ability of earthworms in producing vermicompost.

\section{Materials and Methods}

This research was conducted in the Biology laboratory of FMIPA UNIB from August to October 2016. The design of this study was a Completely Randomized Design consisting of 3 
treatments namely 3 of local earthworms (Pheretima javanica, Pheretima asiatica, and Pontoscolex corethrurus). Each treatment made 7 replications. The maintenance media used in this study is compost made from bagasse mixture with fish waste. The bagasse used is from the seller of sugar cane ice, and fish waste consists of the remaining pieces of fish, stomach contents and gills. Bagasse and fish waste are chopped into smaller pieces and the two ingredients are mixed in a ratio of 2: 1 . For composting, a mixture of organic bagasse and fish waste is added with livestock manure in a ratio of 7:3. Composting takes place \pm 2 weeks and after that, it is ready to be used as a maintenance medium for earthworms.

Maintenance test trials of several species of local earthworms using plastic pots measuring $15 \mathrm{~cm}$ in diameter and $14 \mathrm{~cm}$ in height. Each pot was filled with compost media and included 5 adult worms in each pot. The condition of the media during the study with humidity ranged from $65-85 \%$, media temperature $25-28 \mathrm{oC}$, and average media $\mathrm{pH}$ 6.8. The parameters observed in this study were the time needed for the worm entered the media, population growth and the time needed for the formation of vermicompost from the three species of earthworms. The time needed the worm enters the media is the first step in the worm preference test on the media, starting from the worm placed on the media until the worm enters the media and is no longer visible on the media surface. Population growth, analyzed using the growth rate formula (Soegianto, 1994): $\mathrm{r}=\Delta \mathrm{N} / \Delta \mathrm{t}(\mathrm{r}=$ growth rate, $\Delta \mathrm{N}=$ population growth, $\Delta \mathrm{t}=$ time). The time needed for vermicompost to form is done by estimating the formation of vermicompost $50 \%$. Data on the time needed by the worm entered the media, the growth of the earthworm population and the time needed for the formation of vermicompost was analysed with Analysis of Variance (ANOVA) and Duncan's Test using the SPSS version 20 program.

\section{Result and Discussion}

\section{a. Media Preference Based on Worm duration enter in Media}

Measurement of the time needed for the worm enters the media is one test of preference or level of worm preference for the media. The result of variance analysis (ANOVA) shows that $\mathrm{F}$ counts (37.46)> F Table (3.55). This means that the treatment of the three species of worms significantly affected the time needed for the worm entered the media. In Table 1, it can be seen that the fastest time for worms entered the media was the treatment of worm Pheretima javanica (0.23 minutes), followed by Pheretima asiatica (3.09 minutes) and the longest time the worm entered the media was Pontoscolex corethrurus worm (6, 94 minutes) Statistical analysis results show that the time needed for the three species enter the media are significantly different $(\mathrm{p}<0.05)$. The difference is an indication of different worm preferences for the media being tested. Rukmana (1999), states that the soil or media that is favored by worms, usually the worm response is faster into the media. 
Table 1 . The time needed by the earthworms to enter the media

\begin{tabular}{clcc}
\hline No & Earthworm species & $\begin{array}{c}\text { Time needed } \\
\text { (minutes) } \mathbf{x} \pm \text { SD }\end{array}$ & Notation \\
\hline 1 & Pheretima javanica & $0.23 \pm 1.18$ & $\mathrm{a}$ \\
2 & Pheretima asiatica & $3.09 \pm 0.69$ & $\mathrm{~b}$ \\
3 & Pontoscolex corethrurus & $6.94 \pm 1.99$ & $\mathrm{c}$ \\
\hline
\end{tabular}

Number followed by the same letter indicates no significant different $(\mathrm{p}<0.05)$.

The results of this study indicate that Pheretima javanica prefers a mixture of bagasse and fish waste, compared to Pheretima asiatica and Pontoscolex corethrurus. This is related to the characteristics of its natural habitat, where P. javanica worms are found in garbage piles. The mixture of bagasse and fish waste is not favored by Pontoscolex corethrurus, because the media is very different from the characteristics of its natural habitat in the form of mineral soil and overgrown with grass. In addition, the Pontoscolex corethrurus worm is an endogeic worm, a worm that lives in a layer of topsoil, and generally on mineral soils (But and Lowe, 2011).

\section{The population growth rate}

Maintenance of the three species of earthworms in a mixture of bagasse and fish waste media shows a varied population growth. The results of variance analysis (ANOVA) prove that the $\mathrm{F}$ value is calculated (49.43)> F table (3.55), which means that the three species of worms have a significant influence on the growth rate parameters. The highest growth rate was in the Pheretima javanica worm (5,85 idividual / month), followed by Pheretima asiatica worm $(5,71$ idividual / month) and Pontoscolex corethrurus (0,29 idividual / month). From statistical tests showed that the growth rate of Pheretima javanica and Pheretima asiaca worms was not significantly different, but the growth rate of the two species of worms was significantly different from the rate of growth of Pontoscolex corethrurus worms.

Table 2. The earthworms population growth rate in mixed media of bagasse and fish waste

\begin{tabular}{clcc}
\hline No & Earthworm species & $\begin{array}{c}\text { Population growth rate } \\
\text { (individual / month) } \\
\mathbf{x} \pm \text { SD }\end{array}$ & Notation \\
\hline 1 & Pontoscolex corethrurus & $0,29 \pm 3,98$ & $\mathrm{a}$ \\
2 & Pheretima asiatica & $5,71 \pm 2,49$ & $\mathrm{~b}$ \\
3 & Pheretima javanica & $5,85 \pm 2,41$ & $\mathrm{~b}$ \\
\hline
\end{tabular}

Number followed by the same letter indicates no significant different $(\mathrm{p}<0.05)$. 
The results of this study indicate that Pheretima javanica prefers a mixture of bagasse and fish waste, compared to Pheretima asiatica and Pontoscolex corethrurus. This is related to the characteristics of its natural habitat, where $P$. javanica worms are found in garbage piles. The mixture of bagasse and fish waste is not favored by Pontoscolex corethrurus, because the media is very different from the characteristics of its natural habitat in the form of mineral soil and overgrown with grass. In addition, the Pontoscolex corethrurus worm is an endogeic worm, a worm that lives in a layer of topsoil, and generally on mineral soils (But and Lowe, 2011).

The high growth rate of $P$. Javanica and $P$. asiatica worms has to do with the characteristics of the two worms which have many similarities such as the condition of their natural habitat is the soil with a lot of organic waste. Both species of worms are also often found in landfills. In addition, both species of worms are classified as epigeic worms whose life is on the surface layer of the soil. Lee (1985) states that epigeic worms live in layers of litter or soil surface layers and are also known as compost worms. Generally, epigeic worms have brownish red body pigments and consume litter on the soil surface, for example, Pheretima asiatica. The high growth rates in $P$. javanica and $P$. Asiatica worms are also caused by the two species of worms preferring a mixture of bagasse and fish waste. Experimental data on worm preference on the media shows that both species of worms enter the media faster which is an indication of worms like the media. Unlike the case with Pontoscolex corethrurus worms, where the growth rate is very low. When linked to the level of preference in the media being tested, the results show that the worm requires more time to enter the media. This indicates that the Pontoscolex corethrurus worm does not like the medium of bagasse mixture and fish waste, so the growth rate is lower.

\section{b. Time needed for Vermicompost Formation}

Local land vermicompost is an organic fertilizer which is a by-product in the maintenance of earthworms. The results of this study indicate that the three species of worms have different abilities in degrading the bagasse and fish waste media so that the time needed for the worms produce vermicompost also varies. The result of variance analysis (ANOVA) shows that the $\mathrm{F}$ value is calculated (9.33)> F table (3.55), which means that the three species of worms have a significant effect on the parameters of the formation time of vermicompost. The fastest time to produce vermicompost is Pheretima javanica and Pheretima asiatica, which is 6 weeks, whereas Pontoscolex corethrurus takes 8 weeks.

Vermicompost is an organic fertilizer which is a by-product in the maintenance of earthworms. The results of this study indicate that the three species of worms have different abilities in degrading the bagasse and fish waste media so that the time needed for the worms produce vermicompost also varies. The result of variance analysis (ANOVA) shows that the F value is calculated (9.33)> F table (3.55), which means that the three species of worms have a significant effect on the parameters of the formation time of vermicompost. The fastest time to 
produce vermicompost is Pheretima javanica and Pheretima asiatica, which is 6 weeks, whereas Pontoscolex corethrurus takes 8 weeks.

Table 3. The time needed by earthworms for the of vermicompost formation in mixed media of bagasse and fish waste

\begin{tabular}{cccc}
\hline No & Earthworm species & $\begin{array}{c}\text { Time needed for } \\
\text { vermicompost formation } \\
\text { (weeks) } \mathrm{x} \pm \mathrm{SD}\end{array}$ & Notation \\
\hline 1 & Pheretima javanica & $6 \pm 0,75$ & $\mathrm{a}$ \\
2 & Pheretima asiatica & $6 \pm 0,75$ & $\mathrm{a}$ \\
3 & Pontoscolex corethrurus & $8 \pm 1,40$ & $\mathrm{~b}$ \\
\hline
\end{tabular}

Number followed by the same letter indicates no significant different $(\mathrm{p}<0.05)$.

The results of statistical analysis showed that the time needed to produce vermicompost by Pheretmima javanica and P. asiatica worms was not significantly different, but was significantly different from Pontoscolex corethrurus. The different abilities of worm species in producing vermicompost are related to the level of preference and growth rate in the media tested. Pheretima javanica and P. asiatica worms prefer bagasse pulp and fish waste compared to Pontoscolex corethrurus. Likewise, the growth of Pheretima javanica and P. asiatica worms was also higher in bagasse and fish waste media, when compared to Pontoscolex corethrurus worms. Gunadi (2011) states that the type of Phretima sp. Has the potential to be cultivated. Type Pheretima sp. is a local worm classified as an epigeic worm and has the potential to be used as a compost worm or can be used as a decomposing agent in vermicomposting techniques. Dominguez and Edwards (2011), also suggested that for the needs of worm raising, both for the overhaul of organic matter (making vermicompost) or for cultivating earthworms, the epigeic worm group was the main choice. Epigeic worms are also known as compost worms and are able to process large amounts of organic material and multiply faster than endogeic and anecic worms.

\section{Conclussion}

Basically, three species of earthworms can be reared in a mixed media of bagasse and fish waste. The results showed that the preferences, growth, and ability of worms to produce vermicompost differed significantly in the three species. The preference of worms for the media showed varying results, the most rapid species entering media was Pheretima javanica $(0.23$ minutes) and significantly different from Pheretima asiatica worms (3.09 minutes) and Pontoscolex corethrurus (6.94 minutes). The population growth rates of Pheretima javanica (5.85 idividual / month) and Pheretima asiatica (5.71 idividual / month) were not significantly 
different but were significantly different from Pontoscolex corethrurus ( 0.29 idividual / month). The time needed for the formation of vermicompost in Pheretima javanica (6 weeks) and Pheretima asiatica (6 weeks) was also not significantly different, but it was significantly different from the time needed by Pontoscolex corethrurus worms ( 8 weeks).

\section{References}

[1] But, K.R. and C.N., Lowe, 2011. Controlled cultivation of endogeic and anecic earthworm, in Biology of Earthworm,Soil Biology 24, A. Karaca (ed.). Springer Heidelberg Dordrecht, London, New York.

[2] Davis, J. G., P. Brown, C. Evans J. Mansfield. 2004. The integration of foliar aplied saeweed and fish into the fertility management of organically grown sweet papper. Organic Farming Research Fondation Project. North Carolina State University.

[3] Dominquez, J., C.A. Edwards, 2011. Biology and ecology of earthworm species for vermicomposting: In Vermiculture Technology. Ed. by Clive A. Edwards. CRC Press, London.

[4] Edwards, C. A. And J. R. Lofty. 1972. Biology of earthworm. Chapman and Hall, London.

[5] Gunadi, B., 2011. The status of vermicomposting in Indonesia: In Vermiculture Technology. Ed. by Clive A. Edwards. CRC Press, London.

[6] Kavdir, Y. and R. Ilay, 2011. Earthworms and soil structure, in Soil Biology: Biology of Earthworm. Springer Heidelberg Dordrecht, London, New York.

[7] Lee, K.E., 1985. Earthworm, their ecology and relationships with soils and land use. Academic Press, London.

[8] Rahimah, M. Mardhiansyah, D. Yoza. 2015. Pemanfaatan kompos berbahan baku ampas tebu (Saccharum sp.) dengan bioaktivator Trichoderma spp. Sebagai media tumbuh semai Acacia craasicarpa. JOM Faperta 2(1): 1-16.

[9] Rukmana, R. 1999. Budidaya Cacing Tanah. Kanisius. Yogyakarta

[10] Soegianto, J. 1994. Ekologi Kuantitatif: Metode analisis populasi dan komunitas. Usaha nasional, Surabaya. 